\title{
Grounding line proximal sediment characteristics at a marine-based, late-stage ice stream margin
}

Denise Christina Rüther ${ }^{1,2}$, Monica Winsborrow ${ }^{1}$, Karin Andreassen ${ }^{1}$ and Matthias Forwick ${ }^{3}$

1 Centre for Arctic Gas Hydrate, Environment and Climate (CAGE), Department of Geology, UiT - The Arctic University of Norway, Troms $\varnothing$, Norway

2 Western Norway University of Applied Sciences, Sogndal, Norway

3 Department of Geology, UiT - The Arctic University of Norway, Troms $\varnothing$, Norway

Corresponding author: D. C. Rüther, Western Norway University of Applied Sciences, Postbox 133, NO-6851 Sogndal, Norway. (denise.christina.ruther@hvl.no)

\begin{abstract}
Geomorphological evidence suggests that ice streams undergo frequent dynamic changes towards the end of their life cycles, while associated sedimentary characteristics and processes remain poorly understood. Here, we present new sedimentological data from a Late Weichselian marine-based ice stream in upper Bjørnøyrenna, northern Barents Sea, which experienced accelerated flow, intense calving of large icebergs, ice stream stagnation, ice shelf formation and disintegration. Observed till characteristics give support to the idea of spatially and temporally variable basal drag underneath ice streams. In addition, fast flow may have been accommodated in dilatant deforming till as well as through basal sliding over sticky spots of stiffer till. The grounding zone is shown to be highly transient and spatially variable during the final ice stream readvances, thus rendering the categories subglacial/ proglacial little applicable. In line with previous radiocarbon dates, we find that uppermost Bjørnøyrenna was deglaciated prior to $\sim 11.3 \mathrm{k}-12.0 \mathrm{k}$ cal a BP. Finally, the provenances for the latest ice stream advance and an older ice flow event are inferred based on a novel way of using element geochemistry, helping define ice dome configuration in the northern Barents Sea.
\end{abstract}

Keywords 
ice stream dynamics, mega-scale glacial lineations, grounding line proximal sedimentation, Late Weichselian deglaciation, northern Barents 


\section{Introduction}

Behaviour of West Antarctic ice streams include acceleration, slow-down, stagnation, reactivation and flow switching (e.g. Anandakrishnan et al. 2001; Joughin et al. 2004; Catania et al. 2006; Hulbe and Fahnestock 2007). As ice stream beds are amongst the least accessible environments on earth, knowledge of landforms produced by such observed dynamic ice stream behaviour is predominantly derived from palaeo-settings (e.g. Dowdeswell et al. 2006; Dowdeswell et al. 2008; Jakobsson et al. 2011; Winsborrow et al. 2012). The geomorphologic imprint of ice stream acceleration and stagnation has recently been identified in upper Bjørnøyrenna (Bear Island Trough), Barents Sea (Andreassen et al. 2014; Fig. 2), while the study at hand aims at exploring the sedimentary signature of this complex landsystem. The landform model (Andreassen et al. 2014) includes an acoustically transparent sediment body (ATB; Figs 2a and 2c) which encompasses a proglacial sediment apron, as well as subglacially formed mega-scale glacial lineations (MSGL; Stokes and Clark 1999) indicative of fast flow from NNW to SSE. MSGL are superimposed by a network of crevasse-squeeze ridges (Figs $2 \mathrm{a}$ and $2 \mathrm{~b}$ ), inferred to form as the flow regime changes from fast flow to stagnation (Sharp 1985; van der Veen 1998). The preservation of these delicate subglacial landforms is explained by the floating off of the stagnant ice stream and intermittent ice shelf formation (Andreassen et al. 2014). The ATB laps onto a heavily ploughed seafloor locally, while the onlap is obscured by intense iceberg ploughing otherwise (e.g. easternmost Fig. 2a). The dense occurrence and consistent NNW to SSE courses of mega-iceberg ploughmarks, as well as corrugation ridges, observed and documented by Andreassen et al. (2014), suggest the existence of a densely packed matrix of icebergs following abrupt termination of fast flow and subsequent ice shelf collapse (Jakobsson et al. 2011). Mega-iceberg ploughmarks are locally superimposed on NNE to SSW trending streamlined features which represent an older event of ice streaming, possibly dating to LGM and/ or early deglaciation (red arrows in Fig. 2a). In summary, geomorphologic and acoustic data presented by Andreassen et al. (2014) show two generations of ice movement; the latter of which was deposited during the final stages of deglaciation when Bjørnøyrenna Ice Stream experienced accelerated flow, intense calving of large icebergs, ice stream stagnation, ice shelf formation and disintegration. Based on similarities between the youngest ice stream landform assemblage and existing surge landform models for terrestrial and tidewater glaciers (Evans and Rea 1999; Ottesen and Dowdeswell 2006) as well as indications for repeated stagnation and reactivation of 
Bjørnøyrenna Ice Stream prior to its final retreat stage (Bjarnadóttir et al. 2014), this dynamic behaviour is referred to as one surge cycle by Andreassen et al. (2014).

Here, we investigate the sedimentological signature of this well-preserved ice stream landform assemblage and thereby test whether the complexity of the geomorphology is reflected in the sediment characteristics. For this purpose, five sediment gravity cores are analysed and disclose information on the timing of deglaciation, the dynamic formation of MSGLs, the transient nature of subglacial to glaciproximal processes and enable the distinction of glacial events with differing source areas based on lithologies and geochemistry.

\section{Study area}

With a length of $850 \mathrm{~km}$ and width up to $180 \mathrm{~km}$ Bjørnøyrenna is the largest cross-shelf trough on the formerly glaciated Barents Sea continental shelf (Fig. 1). Bjørnøyrenna Trough Mouth Fan (TMF), built up over multiple glaciations, is the largest TMF along the northwestern European margin (Vorren and Laberg 1997; Fig. 1), illustrating the importance of Bjørnøyrenna ice streams for sediment discharge. Several recent studies have shed light on ice stream configuration and the dynamic nature of the Barents Sea Ice Sheet (BSIS) during Late Weichselian (Andreassen et al. 2008; Ottesen et al. 2008; Winsborrow et al. 2010; Bjarnadóttir et al. 2014). In upper Bjørnøyrenna ice flowed from north-east and north during an early phase of deglaciation, before shifting to a north-western source during later stages of deglaciation (Bjarnadóttir et al. 2014). This reconstruction implies that the main ice divide was centred over Storbanken and Kong Karls Land during LGM and early deglaciation (Bondevik et al. 1995; Ottesen et al. 2005; Fig. 1), while splitting up into several short-lived ice dome positions as the ice sheet thinned during late deglaciation (Salvigsen et al. 1995; Dowdeswell et al. 2010; Bjarnadóttir et al. 2014; Fig. 1).

Confining the timing of deglacial events in the Barents Sea remains challenging. Following the onset of deglaciation and deposition of the first retreat stage in outermost Bjørnøyrenna at $16.9 \mathrm{k}$ - $17.5 \mathrm{k}$ cal a BP $\left(14.5 \mathrm{k}{ }^{14} \mathrm{C}\right.$ a BP; Rüther et al. 2011) several retreat stages and ice stream readvances have been identified (Fig. 1) but not time-constrained. By the beginning of the Holocene, the BSIS had entirely disintegrated, as indicated by raised beaches on Kong Karls Land dated to $11.1 \mathrm{k}$ - $11.6 \mathrm{k}$ cal a BP $\left(9.9 \mathrm{k}{ }^{14} \mathrm{C}\right.$ a BP; Salvigsen 1981) and glacimarine conditions south of Nordaustlandet by $11.4 \mathrm{k}-12.6 \mathrm{k}$ cal a BP $\left(10.4 \mathrm{k}{ }^{14} \mathrm{C}\right.$ a BP; Elverhøi and Solheim 1987). Challenges connected to radiocarbon dating in this polar shelf area include scarcity of soft sediment cover (Solheim et al. 1990), low abundance of calcareous 
microfossils and contamination of bulk samples by old carbon (e.g. Hogan et al. 2010). Holocene sedimentation rates have been estimated to $3 \mathrm{~cm} / \mathrm{ka}$ for uppermost Bjørnøyrenna (Elverhøi et al. 1989). Studies of the soft sediment cover in the northern Barents Sea have revealed a thickness of generally less than $10 \mathrm{~m}$ with a stratigraphy consisting of stiff till, soft till/ glaciproximal diamicts and 0.2 to $1 \mathrm{~m}$ of recent distal glacimarine diamict/ mud (Elverhøi et al. 1989; Solheim et al. 1990; Hogan et al. 2010). The study area coincides approximately with the contemporary Polar Front position (Fig. 1) with cold fresh Arctic waters occurring northwards and warm saline Atlantic waters dominating to the south (Pfirman et al. 2013). The front position is largely topographically controlled; it extends just south of $74^{\circ} \mathrm{N}$ over Spitsbergenbanken and Sentralbanken, while reaching its northernmost position at about $77^{\circ} \mathrm{N}$ in Bjørnøyrenna.

\section{Materials and methods}

Five sediment gravity cores were collected in 2010 using the R/V Jan Mayen's $6 \mathrm{~m}$ long gravity corer with an inner diameter of $10.2 \mathrm{~cm}$. Core locations were chosen with respect to observed glacial landforms and for brevity we use short IDs to refer to the various cores throughout this paper (Fig. 2a, Table 1). Physical properties of the sediments (including wet bulk density and magnetic susceptibility) were measured with a Geotek Multi Sensor Core Logger (Weber et al. 1997). Cores were subsequently opened, described, photographed, xradiographed and measured for undrained shear strength with the fall cone test (Hansbo 1957). In order to quantify clast content throughout the cores, dense anomalies larger than one millimetre were counted in two-centimetre-intervals on x-radiographs (Grobe 1987). A total of 75 subsamples were analysed for water content and grain-size distribution. Coarse and fine fractions ( $>63 \mu \mathrm{m}$ and $<63 \mu \mathrm{m}$ respectively) were separated by wet sieving, and the sand fraction was further split into standard sedimentological size fractions (Wentworth 1922; Friedman and Sanders 1978) by means of dry sieving. The gravel fraction was excluded from the cumulative summaries shown in Figs 3 and 4. Bulk measurements with a Beckman Coulter LS-230 laser particle size analyser at $0.004 \mu \mathrm{m}$ resolution were used to further differentiate material $<63 \mu \mathrm{m}$ into size fractions according to Friedman and Sanders (1978). To prepare for laser scanning the sediments were dispersed in distilled water with $2 \%$ sodium hexametaphosphate and left in an ultrasonic bath for 5 minutes. All cores were scanned with an Avaatech XRF core scanner with $12 \mathrm{~mm}$ cross-core slit size and $5 \mathrm{~mm}$ down-core slit size using the following settings: $10 \mathrm{kV}, 1000 \mu \mathrm{A}$, no filter; $30 \mathrm{kV}, 2000 \mu \mathrm{A}$, Pd-thick filter. The raw data were processed using WinAxil version 4.5.6. Specific ratios, e.g. $\mathrm{Ca} / \mathrm{Fe}, \mathrm{Si} / \mathrm{Al}$ or 
$\mathrm{K} / \mathrm{Ti}$ are commonly used to minimize the influence of matrix effects (Tjallingii et al. 2007; Weltje and Tjallingii 2008). They are powerful environmental and/ or provenance indicators in some areas (Croudace et al. 2006; Richter et al. 2006), but may not be applicable in places with differing geology and environmental conditions. As reference studies for the northern Barents Sea do not exist, we explore the effect of single elements in the following way: XRF returns for single elements are divided over the sum of returns for the most abundant elements (i.e. $\mathrm{Al}, \mathrm{Si}, \mathrm{S}, \mathrm{Cl}, \mathrm{K}, \mathrm{Ca}, \mathrm{Ti}, \mathrm{Fe}, \mathrm{Rh}, \mathrm{Rb}, \mathrm{Sr}$ and $\mathrm{Zr}$ ); results are quasi-concentrations of single elements which we refer to as amounts. Accelerator Mass Spectrometry (AMS) ${ }^{14} \mathrm{C}$ dating was carried out on molluscs and bulk foraminifera at the Poznan and NOSAMS radiocarbon laboratories (Table 2). Age calibration is based on the Marine09 calibration curve (Reimer et al. 2009) and the software Calib 7.0 (Stuiver and Reimer 1993). To express the regional difference with respect to the global mean marine reservoir effect we use a $\Delta R$ value of -124 \pm 31 , the weighted average of two $\Delta \mathrm{R}$ values from Franz Josef Land (Forman and Polyak 1997). Compared to weighted mean $\Delta \mathrm{R}$ values from western Spitsbergen (Mangerud et al. 2006) these samples are at larger geographic distance, while their deglaciation history and associated water mass variability are considered more representative for the north-western Barents Sea (e.g. Koç et al. 2002).

\section{Lithostratigraphy}

Based on lithology, observed structures, physical properties and element geochemistry the cored sediments were divided into three lithological facies (A-C, Table 3 and 4, Figs 3 to 5). The following description and interpretation begins with the oldest lithofacies $\mathrm{C}$, differentiated based on landforms that are penetrated by different cores. Thereafter, lithofacies $\mathrm{A}$ and $\mathrm{B}$ are presented collectively for all cores.

\subsection{Massive diamict (lithofacies C) - subglacial traction till?}

Dark to very dark grey massive diamict with a sandy silt matrix and abundant granule- to cobble-sized clasts is the lowermost facies in all five cores. For the two shortest cores: 359, located on the flank of a MSGL ridge, and 356, taken from the bottom of a large iceberg pit, extremely stiff diamict was sampled in the core cutter and catcher, likely preventing further penetration. Notably, the stiff till could not be investigated further and is not part of lithofacies C. Core 354, taken from the top of the streamlined ridge from an older glacial event, penetrates $35 \mathrm{~cm}$ of massive diamict. Cores 358 and 357, located on the more pronounced, eastern MSGL ridge and on the proposed proglacial sediment apron, recovered 
the longest intervals of massive diamicts with $150 \mathrm{~cm}$ and $185 \mathrm{~cm}$ respectively. At the base of the short cores 359 and 356 a few centimetres of soft diamict are recovered, but the description of lithofacies $\mathrm{C}$ is predominantly based on cores 354, 357 and 358 (Table 3). Water content is low and decreases downcore, with values ranging from 20 to $24 \%$. Shear strength is relatively low with $5 \mathrm{kPa}$ on average, but increases abruptly to $12 \mathrm{kPa}$ at the bases of all cores. Wet bulk density ranges predominantly from 1.8 to $2.0 \mathrm{~g} / \mathrm{cm}^{3}$, with regular variations every 2 to $4 \mathrm{~cm}$. Magnetic susceptibility varies largely throughout this facies with peak values likely corresponding to single magnetic clasts. Aluminium and sulphur amounts ( $\mathrm{Al} /$ sum and $\mathrm{S} / \mathrm{sum})$ are inversely correlated in all cores, the relationship being less obvious in core 354. Calcium and titanium amounts $(\mathrm{Ca} / \mathrm{sum}$ and $\mathrm{Ti} / \mathrm{sum})$ are relatively constant in lithofacies C. In all but core 354 iron/ calcium ratios (Fe/Ca ratios) are significantly lower throughout lithofacies C as compared to overlying lithofacies A and B (Figs 3 and 4). Variations of the $\mathrm{Fe} / \mathrm{Ca}$ ratio across lithological boundaries can be attributed to changes in calcium amounts as iron amounts do not exhibit any clear trends throughout the different lithofacies.

Abundant clasts as well as absence of sedimentary structures (Fig. 5c; lower parts of Figs 5a and 5b) and (trace) fossils suggest a proximal glacial source for this lithofacies (e.g. Powell 1984). The relatively low water content and abrupt downcore increase in shear strength within this lithofacies point to a subglacial rather than glacimarine source of sedimentation (Tulaczyk et al. 1998; Ó Cofaigh et al. 2005; Ó Cofaigh et al. 2007; Reinardy et al. 2011). Based on their lithologies and physical properties, the soft, massive diamicts in all cores (354, 357 and 358) are suggested to be subglacial traction tills (sensu Evans et al. 2006), formed by a combination of deformation and lodgement processes under relatively high porewater pressures. Core-to-core differences in this lithofacies are probably related to varying core locations with respect to identified landforms (Table 4) and will be discussed in paragraphs $5.2-5.4$

4.2 Stratified sandy diamict and bioturbated sandy silt (lithofacies B and A) - palimpsest sediments

The transition from the massive diamict of lithofacies $\mathrm{C}$ into stratified sandy diamict of lithofacies B is conformable (Figs 5a and 5b). Clast content is similarly high as in the massive diamict, while water content is slightly higher and increases upwards from 22 to $31 \%$ (Table 3). Wet bulk density decreases to $\sim 1.6 \mathrm{~g} / \mathrm{cm}^{3}$. The upper contact into bioturbated sandy silt of 
lithofacies $\mathrm{A}$ is gradational (Figs 5a and 5b). Lithofacies $\mathrm{A}$ is not present in the two cores at relatively shallow water depths (358 and 359; Table 3). Lithofacies A and B are primarily differentiated due to significantly fewer clasts ( 7 vs. 26 on average) and a finer matrix in the uppermost sandy silt comprising lithofacies A. In the finer-grained topmost sediments of lithofacies A, water content increases further with an average of $38 \%$ and wet bulk density decreases to $1.4 \mathrm{~g} / \mathrm{cm}^{3}$. Aluminium and sulphur amounts are generally inversely correlated throughout lithofacies $\mathrm{A}$ and $\mathrm{B}$, while calcium and titanium are positively correlated in all but core 354 (Figs 3 and 4). Fe/Ca ratios increase throughout lithofacies B as compared to the underlying till and tend to be constant in lithofacies A. Again, it seems that calcium amounts are the main driver of this trend. Biogenic clasts, mostly foraminifera, occur sparsely throughout the stratified sandy diamict (lithofacies B) and with increased abundance in the topmost bioturbated sandy silt (lithofacies A). Five of six AMS radiocarbon dates are taken from within the stratified sandy diamict; these include two molluscs of the Astarte family and bulk foraminifera picked from three different cores (Fig. 5; Table 2). The calibrated modes span from $\sim 2340$ cal a BP to $\sim 11790$ cal a BP. One mollusc in living position (Astarte sp.) was picked from the uppermost sandy silt and constrains the onset of lithofacies A to $\sim 2050$ cal a BP.

The abrupt increase in sand at the expense of clay content, together with sustained high clast content at the boundary between lithofacies $\mathrm{C}$ and $\mathrm{B}$, can be explained by a proximal source for coarse material in the form of a glacier front (e.g. Elverhøi et al. 1980) or, alternatively, as an erosional product of strong bottom currents (e.g. Vorren et al. 1983). The relatively young radiocarbon dates obtained strengthens the latter explanation. The considerable amount of granule- to pebble-sized clasts is unlikely to reflect iceberg rafting during the Holocene alone as the study area receives few icebergs in recent times (Vinje 1985). We consider clasts to be remnants after winnowing of fine-grained material, thus representing a lag deposit (Vorren et al. 1984). Stratification of the sandy diamict (best developed in core 354; Fig. 5a) suggests that it was formed through both erosion and deposition during periods with varying bottom current strengths. The two northern cores (358 and 359) retrieved from shallowest water depths lack the topmost bioturbated sandy silt with fewer clasts than in lithofacies B. These lithological differences indicate that bottom currents remained strong and erosive at the shallower northern sites (cores 358 and 359), while winnowing was reduced and conditions for benthic organisms ameliorated in slightly deeper waters during the last $\sim 2 \mathrm{k}$ cal a (cores 357, 356 and 354). Also at the deeper sites, bottom currents remain important, as evidenced 
by low clay content in the uppermost sandy silts. These observations are in line with Elverhøi et al. (1989) who found that recent glacier-distal sedimentation in the northern Barents Sea is largely controlled by water depth with the preservation of diamicts above $200 \mathrm{~m}$ due to winnowing and deposition of mud below $200 \mathrm{~m}$ where winnowed material from banks and rain-out from sea ice are the major contributors. In summary, lithofacies A and B can best be described as palimpsest sediments (Vorren et al. 1984) composed of coarse lag sediments, redeposited sediments, rain-out from sea ice and biogenic clasts.

\section{Discussion}

In the following, we start by discussing the reliability of presented radiocarbon dates to constrain the timing of last deglaciation. Secondly, we note the significance of the coexistence of soft and stiff tills for MSGL formation. Further, we discuss if the geomorphological distinction between proglacial and subglacial sediments suggested by Andreassen et al. (2014) is also reflected in sedimentary characteristics. Finally, we explore how new geochemical proxies can be used to strengthen and specify provenance established based on geomorphological data.

\subsection{Minimum deglaciation age}

Despite close proximity to an inferred grounding line, pure deglacial deposits are absent as till is directly overlain by winnowed sediments in the presented cores from northernmost Bjørnøyrenna. Large parts of these winnowed sediments are likely to be redeposited glacial and deglacial sediments, including a mixture of reworked older and contemporaneous biogenic clasts. Ages obtained from bulk foraminifera at comparable levels in cores 356 and 357 , resulted in widely different calibrated modes with $\sim 11.8 \mathrm{k}, \sim 3.5 \mathrm{k}$ and $\sim 2.3 \mathrm{k}$ cal a BP respectively (Table 2). During picking old and reworked-looking foraminifera were avoided. While we cannot rule out contamination by older reworked foraminifera entirely, we argue in the following that the lithofacies boundary is time-transgressive and that $\sim 11.8 \mathrm{k}$ cal a BP is a reliable minimum deglaciation age for the area. As summarised in paragraph 2, 11.8k cal a $\mathrm{BP}$ is also in line with earlier attempts to time-constrain the deglaciation in the northern Barents Sea based on terrestrial dates from Kong Karls Land (Salvigsen 1981) and marine dates south off Nordaustlandet (Elverhøi and Solheim 1987). Bottom currents in the northern Barents Sea form as a combination of mean currents, tides and dense brine formation (Elverhøi et al. 1989). Relatively high bottom current velocities are measured in the area of the Persey and Hopen-Bjørnøya currents which transport Arctic water south-westwards across 
the study area towards Spitsbergenbanken (Loeng 1983; Pfirman et al. 2013). The exact position of the Persey Current is likely to have varied during the Holocene in response to migration of the Polar Front which probably had its northernmost position from $9.5 \mathrm{k}-7.5 \mathrm{k}$ cal a BP and southernmost position from 4.0k - 2.0k cal a BP (Ślubowska-Woldengen et al. 2008). Core 354 which returned the deglaciation age $\sim 11.8 \mathrm{k}$ cal a BP is located 24 to $35 \mathrm{~km}$ south of the other cores and at slightly deeper water depth. Thus, it may have experienced less erosion, particularly during early Holocene. Additional evidence for the time-transgressive nature of the lithofacies boundaries can be derived from the element geochemistry. Over an interval of $10 \mathrm{~cm}$ in the lowermost sandy diamict of core 354 (Fig. 3), aluminium amounts are significantly higher than sulphur amounts. The same signal is condensed to a few cm's in the northern cores 356, 357, 358 and 359 (Figs 3 and 4).

\subsection{Sediment composition of mega-scale glacial lineations (MSGLs)}

The geomorphological signature of the final stage of a marine-based ice stream has been interpreted to show very rapid flow during a surge-type advance (Andreassen et al. 2014). By studying sediment cores sampling the material that MSGLs are built of, we can gain insights into the mechanisms by which fast flow is initiated and maintained. Based on the recovery of soft traction tills in cores 357 and 358 it is reasonable to suggest that fast flow during the ice stream advance was accommodated by a dilatant deforming till layer (Dowdeswell et al. 2004; Ó Cofaigh et al. 2007). However, core 359, located at the edge of a subdued MSGL, only penetrated $24 \mathrm{~cm}$ and the core cutter and catcher recovered very stiff till. There are at least two plausible explanations for the occurrence of soft and stiff tills at two neighbouring sites, which both are characterized by MSGLs and crevasse-squeeze ridges. Firstly, the combination of these particular landforms indicate that the mode of ice flow changed abruptly from fast to stagnant (Sharp 1985), possibly due to a change in the basal thermal regime. In fine-grained till, a negative thermal energy balance may lead to supercooling of pore water and dewatering (Christoffersen and Tulaczyk 2003), which could explain stiff till sampled in core cutter and catcher of core 359. Secondly, the penetration of soft and stiff till in two locations representing the same geomorphological settings is also consistent with increasing evidence for spatially and temporally variable basal drag (Alley 1993). Fast flow can be accommodated in dilatant deforming till as well as through basal sliding over sticky spots; with a transient occurrence of the two end-members in space and time (Piotrowski et al. 2004; King et al. 2009; Larter et al. 2009). It has been shown that MSGLs actively form in areas of dilatant deforming till and undergo significant changes by erosion and deposition on decadal 
timescales (Smith et al. 2007; King et al. 2009). Thus the observation of stiff till at the flank of a less pronounced MSGL (core 359) may imply that till which was once softer and actively deforming into MSGLs, stiffened and became a sticky spot. As sticky spots developed, fast flow was likely accommodated through basal sliding over a thin water film resulting in more subdued MSGLs locally. While we deem the second explanation more likely, further tests are dependent on coring equipment capable of penetrating stiff tills.

\subsection{Distinction of proglacial and subglacial sediments}

One of the key geomorphological observations from the Upper Bjørnøyrenna landform model (Andreassen et al. 2014) was a clear distinction between subglacial and proglacial landforms. In this study we are interested to test whether this distinction is as clear as previously suggested and whether it is reflected in the sedimentological characters of the sediments forming these landforms. The part of the ATB suggested to be of proglacial origin (Fig. 2a) has in fact a highly variable character across the ice stream margin which has not been explored earlier. Well-defined lobate fans with relatively smooth surfaces, clearly lapping onto downstream seafloor are best developed for the part of the ice front position where core 357 is located (Fig. 2a). Such low-relief lobes may suggest that upon ice stream shut-down, deforming till was extruded from beneath the glacier margin forming glacigenic debris flow lobes locally (Alley et al. 1989; Powell et al. 1996). Furthest to the east in Fig. 2a, the former grounding line and downstream onlap of an assumed proglacial sediment apron are obscured by heavy iceberg ploughing. Moreover, for the central part of the ATB (farthest west in Fig. 2a), subglacial landforms continue faintly across much of what is expected to be the proglacial apron, while the downstream onlap is partly obscured by iceberg ploughing. An ice margin close to flotation may leave such a faint subglacial signature behind. At locations where the ATB is obscured by iceberg ploughmarks, an instant disintegration of the heavily crevassed ice margin is suggested (Jakobsson et al. 2011; Andreassen et al. 2014). Cores 357, 358 and 359 penetrate diamicts that are attributed to the latest ice stream advance and shutdown. Following the model proposed by Andreassen et al. (2014) and as discussed in paragraph 5.2, cores 358 and 359 sample subglacial traction till from an area characterized by MSGL (dilatant till) and crevasse-squeeze ridges (till remoulded into stagnation features). Further, material in core 357 should contain till reworked into glacigenic debris flow lobes of proglacial origin. These assumptions are challenged in this study. Sedimentologically, it is difficult to distinguish glacigenic debris flow deposits from subglacial till, in particular from sediment cores where the overall geometry is not apparent (Laberg and Vorren 2000). 
However, based on identical lithologies, physical properties and element geochemical signature in the massive diamicts in cores 358 and 357, we conclude that both of them represent tills emplaced during the same ice stream advance and under comparable circumstances. Interestingly, despite of the massive character on the macro-scale, diamicts in cores 358 and 357 seem to exhibit a characteristic vertical composition as reflected by comparable geochemical signals throughout the tills. This may indicate that the ATB was formed through continuous sediment accretion, with higher accretion rates towards MSGL crests in line with latest suggestions by Spagnolo et al. (2016). In our opinion, the apparent resemblance of the geochemical signatures in cores 358 and 357, renders major reworking through sediment failure in glacigenic debris flows, in the latter location unlikely. Based on revisited and new evidence, namely the lateral geomorphological variability of Andreassen et al.'s (2014) apron and presented geochemical results, we suggest to avoid the categories subglacial/ proglacial entirely. Rather, the frontal ATB represents the imprint of a transient grounding zone where grounding line proximal subglacial traction tills were deposited during the final phases of ice stream shut-down.

\subsection{Element geochemistry as proxy for provenance studies in the Barents Sea}

In the following, we test the applicability of element geochemistry in narrowing down provenance areas for two different ice flow events. Geomorphological studies (Andreassen et al. 2014; Bjarnadóttir et al. 2014) suggest that an ice advance from the NNE emplaced the streamlined ridges sampled by core 354 during LGM or early deglaciation, while the younger ice stream advance from the NNW is recorded in cores 358 and 357 (Figs 2a and 6). Till in core 354 differs from the almost indistinguishable till intervals in cores 357 and 358 with regard to lithology of the matrix and element geochemistry (Table 4, Figs 3 and 4). The average sand content in the till matrix in cores 357 and 358 exceeds $30 \%$, whereas it remains below $25 \%$ in core 354 (Table 4). More importantly for the provenance study, the till in core 354 has a unique geochemical signature, which differs significantly from those in cores 357 and 358. In summary, the till in core 354 has significantly lower calcium and titanium amounts accompanied by higher sulphur and iron amounts (Table 4). In most studies, lower values of $\mathrm{Fe} / \mathrm{Ca}$ (or higher values of $\mathrm{Ca} / \mathrm{Fe}$ ) ratios are used as andicators of the relative importance of biogenic carbonate production over terrigenous sources (e.g. Croudace et al. 2006). However, in the tills of all the studied cores, ratio values are lower than in overlying palimpsest sediments (i.e. amounts of calcium are relatively higher). Low Fe/Ca ratio may indicate terrigenous rather than biogenic $\mathrm{Ca}$-sources in areas where carbonate rocks dominate; 
illustrating that also established ratios have to be adjusted to local conditions. Another argument in favour of using ratios over the sum of the most abundant elements, is that they can be interpreted as quasi-concentration. On the contrary, it is not apparent whether a change in a simple ratio, based on two elements, is due to the increase of the numerator or decrease of the denominator.

Cenozoic to Mesozoic sedimentary bedrock dominates the Barents Sea (Sigmond 1992). Early Cretaceous clastic sedimentary bedrock and several windows of Late Jurassic-Early Cretaceous clastic sedimentary bedrock (with layers of limestone and coal) occur in both upstream directions (NNW and NNE; Fig. 6). While Cretaceous limestones are potential sources for observed higher calcium amounts in the tills of cores 358 and 357, it is suggested that both elevated calcium and titanium amounts from the latest advance are better explained by sediment supply from more distal sources. Limestone of Carboniferous-Permian age, exposed on Nordaustlandet and subcropping offshore, is suggested to be the source of particularly carbonate-rich sediments between Nordaustlandet and Kong Karls Land (Elverhøi et al. 1989). High titanium amounts in the tills emplaced during the late deglaciation (cores 357 and 358; Figs 3, 4 and 6) may reflect an influence of subcropping Triassic-Early Cretaceous diabase around Kong Karls Land. The source area for the till deposited during LGM/ early deglaciation ice flow (core 354) is dominated by clastic sedimentary bedrock with importance of sandstone and coal which results in relatively higher amounts of iron and sulphur (Figs 3 and 6). The provenance established here based on element geochemistry supports earlier arguments based on geomorphology alone (Andreassen et al. 2014; Bjarnadóttir et al. 2014), suggesting that the LGM ice dome over Storbanken and Kong Karls Land (Bondevik et al. 1995; Ottesen et al. 2005; Figs 1 and 6) was responsible for flow from the NNE. Thinning of the BSIS towards late deglaciation caused ice dome migration and establishment of several smaller, short-lived ice divides (Fig. 1). The ice divide between Nordaustlandet and Kong Karls Land (Salvigsen et al. 1995; Figs 1 and 6) is the most likely source area for the latest ice stream advance from NNW. The agreement between geomorphology and element geochemistry in pinpointing provenance areas, shows that the approach of using single elements over the sum of most abundant elements may be more straight forward in areas where element geochemistry, clay mineralogy and heavy mineral analyses are not well established.

\section{Conclusions}


New sedimentological data from a complex and well-preserved ice stream landsystem in upper Bjørnøyrenna, northern Barents Sea suggest the following:

- $\quad$ Uppermost Bjørnøyrenna was deglaciated prior to $\sim 11.3 \mathrm{k}$ - 12.0k cal a BP.

- The recovery of soft traction till and very stiff till from two adjacent MSGLs, give support to the idea that MSGLs primarily form in soft dilatant till. Fast flow accommodated in a thin water-film over stiff till has possibly resulted in more subdued MSGLs.

- Based on geomorphology the proglacial and subglacial part of the ATB can be distinguished. However, tills from different parts of this sediment accumulation have identical lithological, geotechnical and geochemical characteristics, illustrating the transient nature of the grounding zone.

- Provenance based on element geochemistry strengthen earlier geomorphological studies suggesting the disintegration of the major LGM ice dome over Storbanken and Kong Karls Land and the establishment of a minor ice divide between Nordaustlandet and Kong Karls Land during late deglaciation. The approach of using single elements over the sum of most abundant elements might be of interest for other studies presenting element geochemistry.

Acknowledgments.

We thank the captain and crew of R/V Jan Mayen (now R/V Helmer Hanssen) as well as chief engineer Steinar Iversen for his help in collecting and processing the data. This work was partly supported by the Research Council of Norway through its Centres of Excellence funding scheme, project number 223259, “Arctic Gas Hydrate, Environment and Climate (CAGE)". The contribution by MF was funded by Det norske oljeselskap ASA. HiSF bachelor students Aslak Bjøygard, Tove Knutsen, Are Hoff, Øyvind Hole, Monica Hultiin and Brit Vatne are thanked for their contributions to the grain size analyses. We would like to thank two anonymous reviewers for their thorough work and constructive comments.

Abbreviations.

ATB, acoustically transparent sediment body; BSIS, Barents Sea Ice Sheet; MSGL, megascale glacial lineations; NNE, north north-east; NNW, north north-west; TMF, Trough Mouth Fan. 


\section{References}

Alley RB (1993) In search of ice-stream sticky spots. Journal of Glaciology, 39,447-454.

Alley RB, Blankenship DD, Rooney ST \& Bentley CR (1989) Sedimentation beneath ice shelves - the view from ice stream B. Marine Geology, 85,101-120.

Anandakrishnan S, Alley RB, Jacobel RW \& Conway H (2001) The flow regime of Ice Stream $\mathrm{C}$ and hypotheses concerning its recent stagnation. In: The West Antarctic Ice Sheet: Behavior and Environment (eds Alley RB \& Bindschadler RA), American Geophysical Union, Antarctic Research Series, vol. 77, 283-294.

Andreassen K, Laberg JS \& Vorren TO (2008) Seafloor geomorphology of the SW Barents Sea and its glaci-dynamic implications. Geomorphology, 97,157-177.

Andreassen K, Winsborrow MCM, Bjarnadóttir LR \& Rüther DC (2014) Ice stream retreat dynamics inferred from an assemblage of landforms in the northern Barents Sea. Quaternary Science Reviews, 92,246-257.

Bjarnadóttir LR, Winsborrow MCM \& Andreassen K (2014) Deglaciation of the central Barents Sea. Quaternary Science Reviews, 92,208-226.

Bondevik S, Mangerud J, Ronnert L \& Salvigsen O (1995) Postglacial sea-level history of Edgeфya and Barentsфya, eastern Svalbard.

Catania GA, Scambos TA, Conway H \& Raymond CF (2006) Sequential stagnation of Kamb Ice Stream, West Antarctica. Geophys. Res. Lett., 33,L14502.

Christoffersen P \& Tulaczyk S (2003) Signature of palaeo-ice-stream stagnation: till consolidation iduced by basal freeze-on. Boreas, 32,114-129.

Croudace IW, Rindby A \& Rothwell RG (2006) ITRAX: description and evaluation of a new multi-function X-ray core scanner. Geological Society, London, Special Publications, 267,51-63.

Dowdeswell JA, Cofaigh CÓ \& Pudsey CJ (2004) Thickness and extent of the subglacial till layer beneath an Antarctic paleo-ice stream. Geology, 32,13-16.

Dowdeswell JA, Hogan KA, Evans J, Noormets R, Ó Cofaigh C \& Ottesen D (2010) Past icesheet flow east of Svalbard inferred from streamlined subglacial landforms. Geology, 38,163-166.

Dowdeswell JA, Ottesen D, Evans J, Ó Cofaigh C \& Anderson JB (2008) Submarine glacial landforms and rates of ice-stream collapse. Geology, 36,819-822.

Dowdeswell JA, Ottesen D \& Rise L (2006) Flow switching and large-scale deposition by ice streams draining former ice sheets. Geology, 34,313-316.

Elverhøi A, Liestøl O \& Nagy J (1980) Glacial erosion, sedimentation and microfauna in the inner part of Kongsfjorden, Spitsbergen. Norsk Polarinstitutt Tidskrift, 172,33-61.

Elverhøi A, Pfirman SL, Solheim A \& Larssen BB (1989) Glaciomarine sedimentation in epicontinental seas exemplified by the northern Barents Sea. Marine Geology, 85,225250.

Elverhøi A \& Solheim A (1987) Late Weichselian glaciation of the northern Barents Sea - a discussion. Polar Research, 5,285-287.

Evans DJA, Phillips ER, Hiemstra JF \& Auton CA (2006) Subglacial till: Formation, sedimentary characteristics and classification. Earth-Science Reviews, 78,115-176.

Evans DJA \& Rea BR (1999) Geomorphology and sedimentology of surging glaciers: a landsystems approach. Annals of Glaciology, 28,75-82.

Forman SL \& Polyak L (1997) Radiocarbon content of pre-bomb marine mollusks and variations in the ${ }^{14} \mathrm{C}$ Reservoir age for coastal areas of the Barents and Kara Seas, Russia. Geophysical Research Letters, 24,885-888.

Friedman GM \& Sanders JE (1978) Principles of Sedimentology. New York, John Wiley \& Son. 
Grobe H (1987) A simple method for the determination of ice-rafted debris in sediment cores. Polarforschung, 57,123-126.

Hansbo S (1957) A new approach to the determination of the shear strength of clay by the fall-cone test. Stockholm, Royal Swedish geotechnical Institute.

Hogan KA, Dowdeswell JA, Noormets R, Evans J \& Ó Cofaigh C (2010) Evidence for fullglacial flow and retreat of the Late Weichselian Ice Sheet from the waters around Kong Karls Land, eastern Svalbard. Quaternary Science Reviews, 29,3563-3582.

Hulbe C \& Fahnestock M (2007) Century-scale discharge stagnation and reactivation of the Ross ice streams, West Antarctica. Journal of geophysical research, 112.

Jakobsson M, Anderson JB, Nitsche FO, Dowdeswell JA, Gyllencreutz R, Kirchner N, Mohammad R, O'Regan M, Alley RB, Anandakrishnan S, Eriksson B, Kirshner A, Fernandez R, Stolldorf T, Minzoni R \& Majewski W (2011) Geological record of ice shelf break-up and grounding line retreat, Pine Island Bay, West Antarctica. Geology, 39,691-694.

Jakobsson M, Mayer L, Coakley B, Dowdeswell JA, Forbes S, Fridman B, Hodnesdal H, Noormets R, Pedersen R, Rebesco M, Schenke HW, Zarayskaya Y, Accettella D, Armstrong A, Anderson RM, Bienhoff P, Camerlenghi A, Church I, Edwards M, Gardner JV, Hall JK, Hell B, Hestvik O, Kristoffersen Y, Marcussen C, Mohammad R, Mosher D, Nghiem SV, Pedrosa MT, Travaglini PG \& Weatherall P (2012) The International Bathymetric Chart of the Arctic Ocean (IBCAO) Version 3.0. Geophysical Research Letters, 39,L12609.

Joughin I, Tulaczyk S, MacAyeal DR \& Engelhardt H (2004) Melting and freezing beneath the Ross ice streams, Antarctica. Journal of Glaciology, 50,96-108.

King EC, Hindmarsh RCA \& Stokes CR (2009) Formation of mega-scale glacial lineations observed beneath a West Antarctic ice stream. Nature Geoscience, 2,585-588.

Koç N, Klitgaard-Kristensen D, Hasle K, Forsberg CF \& Solheim A (2002) Late glacial palaeoceanography of Hinlopen Strait, northern Svalbard. Polar Research, 21,307314.

Laberg JS \& Vorren TO (2000) Flow behaviour of the submarine glacigenic debris flows on the Bear Island Trough Mouth Fan, western Barents Sea. Sedimentology, 47,11051117.

Larter RD, Graham AGC, Gohl K, Kuhn G, Hillenbrand C-D, Smith JA, Deen TJ, Livermore RA \& Schenke H-W (2009) Subglacial bedforms reveal complex basal regime in a zone of paleo-ice stream convergence, Amundsen Sea embayment, West Antarctica. Geology, 37,411-414.

Loeng H (1983) Strømmålinger i tidsrommet 1979-1982 i de sentrale deter av Barentshavet. In: Environmental Conditions in the Barents Sea and Near Jan Mayen (ed. Eide LI) Bergen, Institute of Marine Research.

Mangerud J, Bondevik S, Gulliksen S, Hufthammer AK \& Høisæter T (2006) Marine ${ }^{14} \mathrm{C}$ reservoir ages for 19th century whales and molluscs from the North Atlantic. Quaternary Science Reviews, 25,3228-3245.

Ó Cofaigh C, Dowdeswell JA, Allen CS, Hiemstra JF, Pudsey CJ, Evans J \& J.A. Evans D (2005) Flow dynamics and till genesis associated with a marine-based Antarctic palaeo-ice stream. Quaternary Science Reviews, 24,709-740.

Ó Cofaigh C, Evans J, Dowdeswell JA \& Larter RD (2007) Till characteristics, genesis and transport beneath Antarctic paleo-ice streams. Journal of geophysical research, 112,F03006.

Ottesen D \& Dowdeswell JA (2006) Assemblages of submarine landforms produced by tidewater glaciers in Svalbard. Journal of geophysical research, 111,F01016. 
Ottesen D, Dowdeswell JA \& Rise L (2005) Submarine landforms and the reconstruction of fast-flowing ice streams within a large Quaternary ice sheet: the 2,500km-long Norwegian-Svalbard margin $\left(57^{\circ}\right.$ to $\left.80^{\circ} \mathrm{N}\right)$. Geological Society of America Bulletin, 117,1033-1050.

Ottesen D, Stokes CR, Rise L \& Olsen L (2008) Ice-sheet dynamics and ice streaming along the coastal parts of northern Norway. Quaternary Science Reviews, 27,922-940.

Pfirman SL, Bauch D \& Gammelsrød T (2013) The Northern Barents Sea: Water Mass Distribution and Modification. In: The Polar Oceans and Their Role in Shaping the Global Environment, American Geophysical Union, 77-94.

Piotrowski JA, Larsen NK \& Junge FW (2004) Reflections on soft subglacial beds as a mosaic of deforming and stable spots. Quaternary Science Reviews, 23,993-1000.

Powell RD (1984) Glacimarine processes and inductive lithofacies modelling of ice shelf and tidewater glacier sediments based on Quaternary examples. Marine Geology, 57,1-52.

Powell RD, Dawber M, McInnes JN \& Pyne AR (1996) Observations of the grounding-line area at a floating glacier terminus. Annals of Glaciology, 22,217-223.

Reimer PJ, Baillie MGL, Bard E, Bayliss A, Beck JW, Blackwell PG, Ramsey CB, Buck CE, Burr GS, Edwards RL, Friedrich M, Grootes PM, Guilderson TP, Hajdas I, Heaton TJ, Hogg AG, Hughen KA, Kaiser KF, Kromer B, McCormac FG, Manning SW, Reimer RW, Richards DA, Southon JR, Talamo S, Turney CSM, van der Plicht J \& Weyhenmeyer CE (2009) IntCal09 and Marine09 radiocarbon age calibration curves, 0-50,000 years cal BP. Radiocarbon, 51,1111-1150.

Reinardy BTI, Hiemstra JF, Murray T, Hillenbrand C-D \& Larter RD (2011) Till genesis at the bed of an Antarctic Peninsula palaeo-ice stream as indicated by micromorphological analysis. Boreas,no-no.

Richter TO, Van der Gaast S, Koster B, Vaars A, Gieles R, de Stigter HC, De Haas H \& van Weering TCE (2006) The Avaatech XRF Core Scanner: technical description and applications to NE Atlantic sediments. Geological Society, London, Special Publications, 267,39-50.

Rüther DC, Mattingsdal R, Andreassen K, Forwick M \& Husum K (2011) Seismic architecture and sedimentology of a major grounding zone system deposited by the Bjørnøyrenna Ice Stream during Late Weichselian deglaciation. Quaternary Science Reviews, 30,2776-2792.

Salvigsen O (1981) Radiocarbon Dated Raised Beaches in Kong Karls Land, Svalbard, and Their Consequences for the Glacial History of the Barents Sea Area. Geografiska Annaler. Series A, Physical Geography, 63,283-291.

Salvigsen O, Adrielsson L, Hjort C, Kelly M, Landvik JY \& Ronnert L (1995) Dynamics of the last glaciation in eastern Svalbard as inferred from glacier-movement indicators. Polar Research, 14,141-152.

Sharp MJ (1985) 'Crevasse-fill' ridges: a landform type characteristic of surging glaciers? Geografiska Annaler, 67A,213-220.

Sigmond EMO (1992) Berggrunnskart, Norge med havområder. Målestokk 1:3 millioner. In, Norges geologiske unders $\varnothing$ kelse.

Ślubowska-Woldengen M, Koç N, Rasmussen TL, Klitgaard-Kristensen D, Hald M \& Jennings AE (2008) Time-slice reconstructions of ocean circulation changes on the continental shelf in the Nordic and Barents Seas during the last 16,000 cal yr B.P. Quaternary Science Reviews, 27,1476-1492.

Smith AM, Murray T, Nicholls KW, Makinson K, Ađalgeirsdóttir G, Behar AE \& Vaughan DG (2007) Rapid erosion, drumlin formation, and changing hydrology beneath an Antarctic ice stream. Geology, 35,127-130. 
Solheim A, Russwurm L, Elverhøi A \& Berg MN (1990) Glacial geomorphic features in the northern Barents Sea: direct evidence for grounded ice and implications for the pattern of deglaciation and late glacial sedimentation. Geological Society, London, Special Publications, 53,253-268.

Spagnolo M, Phillips E, Piotrowski JA, Rea BR, Clark CD, Stokes CR, Carr SJ, Ely JC, Ribolini A, Wysota W \& Szuman I (2016) Ice stream motion facilitated by a shallowdeforming and accreting bed. Nature Communications, $\mathbf{7}$.

Stokes CR \& Clark CD (1999) Geomorphological criteria for identifying Pleistocene ice streams. Annals of Glaciology, 28,67-74.

Stuiver M \& Reimer PJ (1993) Extended ${ }^{14} \mathrm{C}$ database and revised CALIB radiocarbon calibration program. Radiocarbon, 35,215-230.

Svendsen JI, Gataullin V, Mangerud J \& Polyak L (2004) The glacial History of the Barents and Kara Sea Region. In: Developments in Quaternary Science (eds Ehlers J \& Gibbard PL), Elsevier, Volume 2, Part 1, 369-378.

Tjallingii R, Röhl U, Kölling M \& Bickert T (2007) Influence of the water content on X-ray fluorescence core-scanning measurements in soft marine sediments. Geochemistry, Geophysics, Geosystems, 8,Q02004.

Tulaczyk S, Kamb B, Scherer RP \& Engelhardt HF (1998) Sedimentary processes at the base of a West Antarctic ice stream: constraints from textural and compositional properties of subglacial debris. Journal of Sedimentary Research, 68.

van der Veen CJ (1998) Fracture mechanics approach to penetration of bottom crevasses on glaciers. Cold Regions Science and Technology, 27,213-223.

Vinje TE (1985) Drift, composition, morphology and distribution of the sea ice fiels in the Barents Sea. Norsk Polarinstitutt Skrifter, 179,26.

Vorren TO, Hald M, Edvardsen M \& Lind-Hansen OW (1983) Glacigenic sediments and sedimentary environments on continental shelves. In: Glacial deposits in North-West Europe (ed. Ehlers J) Rotterdam, A.A.Balkema, 61-73.

Vorren TO, Hald M \& Thomsen E (1984) Quaternary sediments and environments on the continental shelf off northern Norway. Marine Geology, 57,229-257.

Vorren TO \& Laberg JS (1997) Trough mouth fans - palaeoclimate and ice-sheet monitors. Quaternary Science Reviews, 16,865-881.

Weber ME, Niessen F, Kuhn G \& Wiedicke M (1997) Calibration and application of marine sedimentary physical properties using a multi-sensor core logger. Marine Geology, 136,151-172.

Weltje GJ \& Tjallingii R (2008) Calibration of XRF core scanners for quantitative geochemical logging of sediment cores: Theory and application. Earth and Planetary Science Letters, 274,423-438.

Wentworth CK (1922) A Scale of Grade and Class Terms for Clastic Sediments. The Journal of Geology, 30,377-392.

Winsborrow MCM, Andreassen K, Corner GD \& Laberg JS (2010) Deglaciation of a marinebased ice sheet: Late Weichselian palaeo-ice dynamics and retreat in the southern Barents Sea reconstructed from onshore and offshore glacial geomorphology. Quaternary Science Reviews, 29,424-442.

Winsborrow MCM, Stokes CR \& Andreassen K (2012) Ice-stream flow switching during deglaciation of the southwestern Barents Sea. Geological Society of America Bulletin, 124,275-290. 


\section{Figure captions}

Figure 1. Summary of the glacial and deglacial history and indication of study area.

Figure 2. Location of the studied sediment gravity cores in uppermost Bjørnøyrenna, western Barents Sea. (a) Swath-bathymetry showing the published surge landform assemblage (Andreassen et al. 2014) together with the location of cores used in this study. (b) Detailed swath-bathymetry and bathymetric profile across mega-scale glacial lineations and crevassesqueeze ridges. (c) Acoustic chirp profile across the acoustically transparent sediment body.

Figure 3. Lithology, granulometry, physical properties and qualitative element geochemistry for cores 358, 359, 356 and 354 .

Figure 4. Lithology, granulometry, physical properties and qualitative element geochemistry for core 357. See Fig. 3 for key to the lithofacies.

Figure 5. Radiographs and photographs for three selected core intervals (a-c). Same colour coding of lithofacies A-C as in Figs 3 and 4.

Figure 6. Subcropping bedrock for upstream source areas for ice flow during LGM and early deglaciation as well as ice advance during late deglaciation. Semi-transparent bedrock information (Sigmond 1992) overlies dark land areas and bathymetry with white $100 \mathrm{~m}$ contour 


\section{Tables}

Table 1. Sediment gravity cores presented in this study

\begin{tabular}{lllllll}
\hline Core ID & $\begin{array}{l}\text { Short } \\
\text { ID }\end{array}$ & $\begin{array}{l}\text { Latitude } \\
(\mathbf{N})\end{array}$ & $\begin{array}{l}\text { Longitude } \\
(\mathbf{E})\end{array}$ & $\begin{array}{l}\text { Water } \\
\mathbf{d e p t h s} \\
(\mathbf{m})\end{array}$ & $\begin{array}{l}\text { Recovery } \\
(\mathbf{m})\end{array}$ & Relation to landform \\
\hline JM10-354-GC & 354 & $76^{\circ} 53.125^{\prime}$ & $30^{\circ} 50.337^{\prime}$ & 234 & 0.71 & On streamlined older feature \\
JM10-356-GC & 356 & $77^{\circ} 04.324^{\prime}$ & $30^{\circ} 22.964^{\prime}$ & 226 & 0.30 & Within iceberg pit \\
JM10-357-GC & 357 & $77^{\circ} 05.510^{\prime}$ & $30^{\circ} 18.489^{\prime}$ & 215 & 2.17 & On assumed proglacial sediment apron \\
JM10-358-GC & 358 & $77^{\circ} 08.975^{\prime}$ & $30^{\circ} 11.083^{\prime}$ & 195 & 1.75 & On pronounced MSGL ridge \\
JM10-359-GC & 359 & $77^{\circ} 09.014^{\prime}$ & $30^{\circ} 04.984^{\prime}$ & 199 & 0.24 & On less pronounced MSGL \\
\hline
\end{tabular}

Table 2. Uncorrected and calibrated radiocarbon ages presented in this study

\begin{tabular}{|c|c|c|c|c|c|c|c|c|}
\hline Depth in core & $\begin{array}{l}\text { Litho- } \\
\text { facies }\end{array}$ & Material & ${ }^{14} \mathrm{C}$ a BP & 10 & $\begin{array}{l}\text { cal a BP } \\
(\text { mode })^{\mathrm{a}}\end{array}$ & 10 range $\mathrm{a}^{\mathrm{a}}$ & $2 o^{\prime}$ range ${ }^{a}$ & Lab ID \\
\hline $\begin{array}{l}\text { JM10-354- } \\
\text { GC }\end{array}$ & $\mathrm{B}$ & Astarte sp. & 6200 & 40 & $\begin{array}{l}2780 \\
\sim 678\end{array}$ & $6720-6855$ & $6657-6919$ & Poz-51801 \\
\hline \multicolumn{9}{|l|}{$28 \mathrm{~cm}$} \\
\hline $\begin{array}{l}\text { JM10-354- } \\
\text { GC }\end{array}$ & $\mathrm{B}$ & $\begin{array}{l}\text { Bulk } \\
\text { foraminifera }\end{array}$ & 10400 & 65 & $\sim 11790$ & $11568-11948$ & $11356-12021$ & OS-110858 \\
\hline \multicolumn{9}{|l|}{$30-31 \mathrm{~cm}$} \\
\hline $\begin{array}{l}\text { JM10-356- } \\
\text { GC }\end{array}$ & $\mathrm{B}$ & $\begin{array}{l}\text { Bulk } \\
\text { foraminifera }\end{array}$ & 3450 & 25 & $\sim 3450$ & $3409-3523$ & $3363-3567$ & OS-110859 \\
\hline \multicolumn{9}{|l|}{$19-20 \mathrm{~cm}$} \\
\hline $\begin{array}{l}\text { JM10-356- } \\
\text { GC }\end{array}$ & B & $\begin{array}{l}\text { Astarte } \\
\text { elliptica }\end{array}$ & 7060 & 35 & $\sim 7650$ & $7591-7686$ & $7560-7754$ & Poz-51802 \\
\hline \multicolumn{9}{|l|}{$22 \mathrm{~cm}$} \\
\hline $\begin{array}{l}\text { JM10-357- } \\
\text { GC }\end{array}$ & A & Astarte sp. & 2295 & 30 & $\sim 2050$ & $1992-2113$ & $1918-2182$ & Poz-51803 \\
\hline \multicolumn{9}{|l|}{$16 \mathrm{~cm}$} \\
\hline $\begin{array}{l}\text { JM10-357- } \\
\text { GC }\end{array}$ & B & $\begin{array}{l}\text { Bulk } \\
\text { foraminifera }\end{array}$ & 2550 & 30 & $\sim 2340$ & $2310-2422$ & $2268-2530$ & OS-110860 \\
\hline $25-26 \mathrm{~cm}$ & & & & & & & & \\
\hline
\end{tabular}

\footnotetext{
${ }^{\mathrm{a}}$ Calibration based on the Marine09 calibration curve (Reimer et al. 2009) and a $\Delta \mathrm{R}$ value of $-124 \pm 31$ (Forman and Polyak 1997).
} 
Table 3. Properties and interpretation of the observed lithofacies

\begin{tabular}{|c|c|c|c|}
\hline \multirow[t]{2}{*}{ Parameters } & \multicolumn{3}{|l|}{ Lithofacies } \\
\hline & $\mathrm{A}$ & B & $\mathrm{C}$ \\
\hline Thicknesses (cm) & $0-20$ & $10-25$ & $2-185$ \\
\hline Lithology & sandy silt & sandy diamict & silty diamict \\
\hline Structures & bioturbated & stratified & massive \\
\hline Colour (Munsell) & $\begin{array}{l}5 \mathrm{Y} 4 / 2,5 \mathrm{Y} 3 / 2 \\
\text { (dark) olive grey }\end{array}$ & $\begin{array}{l}5 \mathrm{Y} 3 / 2 \\
\text { dark olive grey }\end{array}$ & $\begin{array}{l}2.5 \mathrm{Y} 4 / 1,2.5 \mathrm{Y} 3 / 1 \\
\text { (very) dark grey }\end{array}$ \\
\hline $\begin{array}{l}\text { Clasts }(\#>1 \mathrm{~mm} / \\
2 \mathrm{~cm} \text { interval) }\end{array}$ & $0-26(7)$ & $4-59(26)$ & $12-51(29)$ \\
\hline Shear strength $(\mathbf{k P a})^{\mathrm{b}}$ & 2-11 (4) & $2-7(3)$ & $2-12(5)$ \\
\hline Water content $(\text { wt. } \%)^{\mathbf{b}}$ & $32-53(38)$ & $22-31(25)$ & $20-24(22)$ \\
\hline $\begin{array}{l}\text { Wet bulk density } \\
\left(\mathrm{g} / \mathrm{cm}^{3}\right)^{\mathbf{b}}\end{array}$ & $1.1-1.6(1.5)$ & $1.1-1.9(1.6)$ & $1.8-2.2(1.9)$ \\
\hline Upper unit boundary & top of core & gradational & conformable \\
\hline Lower unit boundary & gradational & conformable & base of core \\
\hline Present in cores & $354,356,357$ & $\begin{array}{l}354,356,357 \\
358,359 .\end{array}$ & $354,357,358$ \\
\hline Interpretation & $\begin{array}{l}\text { Palimpsest } \\
\text { sediment, reduced } \\
\text { bottom currents }\end{array}$ & $\begin{array}{l}\text { Palimpsest } \\
\text { sediment, high } \\
\text { bottom currents }\end{array}$ & $\begin{array}{l}\text { Subglacial traction } \\
\text { till, see Table } 4\end{array}$ \\
\hline
\end{tabular}

${ }^{\mathrm{b}}$ Range; mean value in parenthesis

Table 4. Characteristics of lithofacies $C$ (massive diamict) with respect to sampled landforms in cores 354,357 and 358

\begin{tabular}{llll} 
Cores & $\mathbf{3 5 4}$ & $\mathbf{3 5 7}$ & $\mathbf{3 5 8}$ \\
& & & \\
\hline $\begin{array}{l}\text { Thickness (cm) } \\
\text { Average sand content } \\
\text { in matrix }\end{array}$ & 35 & 185 & 150 \\
$\begin{array}{l}\text { Average Ca/sum ratio } \\
\text { Average Ti/sum ratio }\end{array}$ & $4.2 \%$ & $36 \%$ & $37 \%$ \\
$\begin{array}{l}\text { Average S/sum ratio } \\
\text { Average Fe/sum ratio }\end{array}$ & $1.8 \%$ & $5.9 \%$ & $5.9 \%$ \\
Average Fe/Ca ratio & $47.4 \%$ & $7.2 \%$ & $7.1 \%$ \\
\hline Relation to landform & 11.4 & $1.3 \%$ & $1.3 \%$ \\
& $\begin{array}{l}\text { Downstream of } \\
\text { ATB: on older } \\
\text { streamlined } \\
\text { feature }\end{array}$ & "Proglacial" part & $\begin{array}{l}\text { On ATB: } \\
\text { pronounced }\end{array}$ \\
& & & MSGL \\
\hline
\end{tabular}

